International Journal of Zoological Investigations

Contents available at Journals Home Page: www.ijzi.net

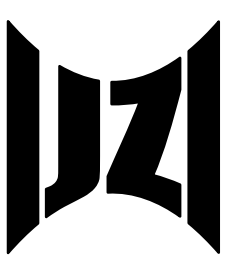

ISSN: 2454-3055

\title{
Growth Performance of the Prawn Macrobrachium rosenbergii Post-Larvae Fed with Probiotic Bacterium, Enterococcus hirae Enriched Artemia franciscana Nauplii
}

Jain I. B., Saravana Bhavan P.*, Manjula T., Dharani C., Kalpana R., Muralisankar T., Aiswaryalakshmi S. and Karthik M.

Department of Zoology, Bharathiar University, Coimbatore 641046, Tamil Nadu, India

${ }^{*}$ Corresponding Author

Received: $4^{\text {th }}$ March, 2020

Accepted: 9th April, 2020

Published online: 30th April, 2020

https://doi.org/10.33745/ijzi.2020.v06i01.009

\begin{abstract}
This study was aimed to investigate whether the bacterium Enterococcus hirae can be used as a probiotic for promoting the growth of the prawn, Macrobrachium rosenbergii post-larvae (PL). Artemia franciscana nauplii were enriched with $E$. hirae at five different serially diluted concentrations $\left(10^{-1}, 10^{-3}, 10^{-5}, 10^{-7}\right.$ and $\left.10^{-9}\right)$. A 45 day feeding trial revealed that the survival, growth, concentrations of total protein, amino acid, carbohydrate and lipid, and activities of protease, amylase and lipase were significantly $(\mathrm{P}<0.05)$ increased in experimental $\mathrm{PL}$, particularly at $1764 \times 10^{-7}, \mathrm{CFU}$. Further, the consortium of the gut microflora of un-enriched Artemia nauplii fed PL showed the presence of Escherichia coli, Klebsiella sp., Citrobacter sp., Acinetobacter sp., Streptococcus sp., Bacillus sp., Staphylococcus sp. and Pseduomonas sp. In E. hirae enriched Artemia nauplii fed PL showed the presence of Enterococcus sp., E. coli, Lactobacillus sp., Acinetobacter sp. and Staphylococcus sp. It was found that the pathogenic bacteria Klebsiella sp., Citrobacter sp., Streptococcus sp. and Pseduomonas sp. were competitively excluded by the colony establishment of Enterococcus sp. in experimental PL. Therefore, E. hirae can be used as a probiotic for promoting the sustainable culture of M. rosenbergii.
\end{abstract}

Keywords: Enterococcus hirae, Artemia nauplii, Prawn, Growth, Survival, Protein, Digestive enzymes, Macrobrachium rosenbergii

Citation: Jain I. B., Saravana Bhavan P., Manjula T., Dharani C., Kalpana R., Muralisankar T., Aiswaryalakshmi S. and Karthik M.: Growth performance of the prawn Macrobrachium rosenbergii post-larvae fed with probiotic bacterium, Enterococcus hirae enriched Artemia franciscana nauplii.. Intern. J. Zool. Invest. 6 (1): 107-121, 2020. https://doi.org/10.33745/ijzi.2020.v06i01.009

\section{Introduction}

Aquaculture practices of the giant river profitable one and this species grows fast in prawn, Macrobrachium rosenbergii is either monoculture or poly-culture with major 
carps worldwide (FAO, 2016). Probiotics are generally supplemented either with feed or additionally given into the culture environment for enhancing the immune response of cultured organisms. They fight against pathogens by impeding adherence in the intestinal mucosa, releasing the gut protective metabolites including antimicrobial substances, bacterial enzymes such as bacteriocins, siderophores, lysozymes and hydrogen peroxides and thereby competitively excluded the pathogenic bacteria (Farzanfar, 2006; Zai et al., 2009; Ninawe and Selvin, 2009; Barman et al., 2013). Probiotics used as an alternative against antibiotics to boost up the immunoprophylactic measures of diseases by colonizing in the gut, altering microbial composition and maintaining the barrier function (Verschuere et al., 2000; ApinesAmar and Amar, 2015; Chen et al., 2017; Mathipa, 2017).

Enterococcus hirae, Enterococcus casseliflavus and Enterococcus durans are frequently occurring components of the intestinal flora of several domestic animal species (Devriese et al., 1987; Ahmed and Baptiste, 2018). Though these are not a part of the normal microbiota in seafood organisms (Boss et al., 2016), the Enterococcus genus were isolated from the intestine of common carp and freshwater prawn M. rosenbergii (Cai et al., 1999). However, Enterococci obtained from food and human samples show virulence characters (Kurekci et al., 2016).

Probiotic feeding treatment for assessment of growth and other physiological and biochemical parameters have widely been reported in aquatic animals; effect of Lactobacillus bacteria on growth performance and digestive enzyme activities in the gilthead sea bream Sparus aurata (Suzer et al., 2008); Lactobacillus acidophilus tested for the better growth performance, haematological parameters and concentration of immunoglobulin in African catfish Clarias gariepinus (Al-Dohail et al., 2009); Bacillus strains (Bacillus pumilus and Bacillus clausii) with antagonistic activity to improve the growth performance and immune responses of Epinephelus coioides (Sun et al., 2010); Bacillus subtilis, Bacillus licheniformis, Lactobacillus sp., Arthrobacter sp. and Vibrio harveyi tested for the growth, non-specific immunity and disease resistance in cobia Rachycentron canadum (Geng et al., 2012); Bacillus sp., Rhodobacter sp., Streptococcus sp., for growth and production of the giant freshwater prawn $M$. rosenbergii (DeMan, 1879) (Ghosh et al., 2016); Bacillus subtilis used as dietary supplement to enhance the growth performance and disease resistance against Vibrio alginolyticus in parrot fish Oplegnathus fasciatus (Liu et al., 2018) and Bacillus subtilis and Bacillus licheniformis for better growth, feed efficiency, body composition and immune parameters in whiteleg shrimp Litopenaeus vannamei (Madani et al., 2018). In this study, Artemia franciscana nauplii was enriched with Enterococcus hirae and fed to M. rosenbergii PL as a live feed for assessing its survival, growth, concentrations of total protein, amino acid, carbohydrate and lipid, and activities of protease, lipase and amylase.

\section{Materials and Methods}

Procurement of Enterococcus hirae (3612) and its Sub Culture:

The lyophilized powder of E. hirae (MTCC 3612) was procured from Microbial Type 
Culture Collection (MTCC), Chandigarh, India. It was subjected to sub-culture with Nutrient broth (Hi-media, India, $\mathrm{pH}, \quad 6.5$ at Temperature, 25 C), contained peptic digestion of animal tissues (5 $\left.\mathrm{g} \mathrm{L}^{-1}\right)$, Beef extract $\left(1.5 \mathrm{~g} \mathrm{~L}^{-1}\right)$, Sodium chloride $\left(5.0 \mathrm{~g} \mathrm{~L}^{-1}\right)$, and Yeast extract $\left(1.5 \mathrm{~g} \mathrm{~L}^{-1}\right)$. The medium (13 g) was mixed with $1 \mathrm{~L}$ of double distilled water in a screw cap container and autoclaved at $121 \mathrm{C}$ for $15 \mathrm{~min}$. A loop of E. hirae was inoculated into the broth and incubated for 24 hours at $37 \mathrm{C}$. The appearance of turbid broth indicates the growth of E. hirae (Fig. 1). The cultured E. hirae was harvested by centrifugation at $5000 \mathrm{rpm}$ for $10 \mathrm{~min}$, washed twice with phosphate buffered saline $(\mathrm{pH}, 7.2)$, weighed and re-suspended in the same buffer. For further usage it was stored at $4 \mathrm{C}$. The suspension $(30 \mu \mathrm{l})$ was spread over the agar plate and the appearance of white colony indicates the growth of $E$. hirae (Fig. 2). $20 \mu \mathrm{l}$ of serially diluted broth (up to $10^{-9}$ ) was spread on nutrient agar for enumerating the CFU in order to optimize it, and the count was 4865 at $10^{-1}, 3264$ at $10^{-3}, 2274$ at $10^{-5}, 1764$ at $10^{-7}$ and 1071 at $10^{-9}$.

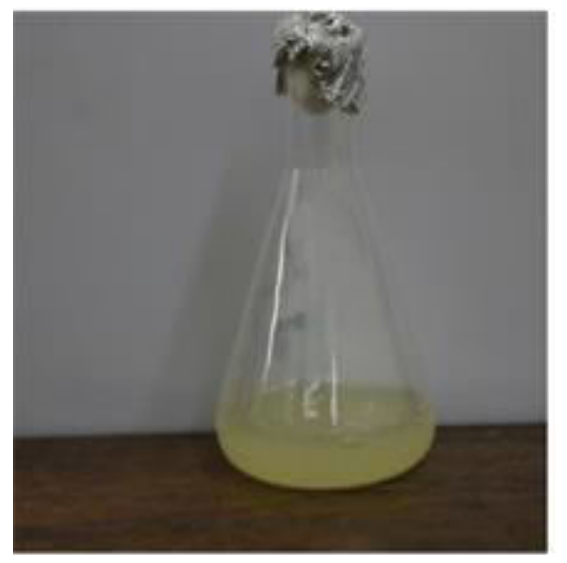

Fig. 1: Mother culture morphology of E. hirae.

Feed Preparation:

All the ingredients used were micro pulverized and sieved $(0.3 \mathrm{~mm})$. For protein source, fishmeal (25\%), groundnut oil cake (25\%) and soybean meal (25\%) were used. For carbohydrate source, wheat bran $(10 \%)$ was used. Then it was steam cooked for 15 $\min$ at 95-100 C and cool at room temperature. BECOSULES capsules (Pfizer Ltd., Mumbai, India) was used for vitamin B complex with vitamin C (1\%). Tapioca flour (5\%) and egg albumin $(7 \%)$ were used as binding agents. Sunflower oil (2\%) was added as lipid source. The dough was prepared with adequate boiled water, pelletized in a manual pelletizer fixed with $3 \mathrm{~mm}$ diameter metal mesh, the threads were collected in aluminum trays and the semidried threads were cut into 3-5 $\mathrm{mm}$ pellets. The pelletized feed was dried under room temperature until the moisture content reached less than $10 \%$. The prepared feed was subjected to proximate composition analysis by adopting AOAC methodology (1995) (Table 1).

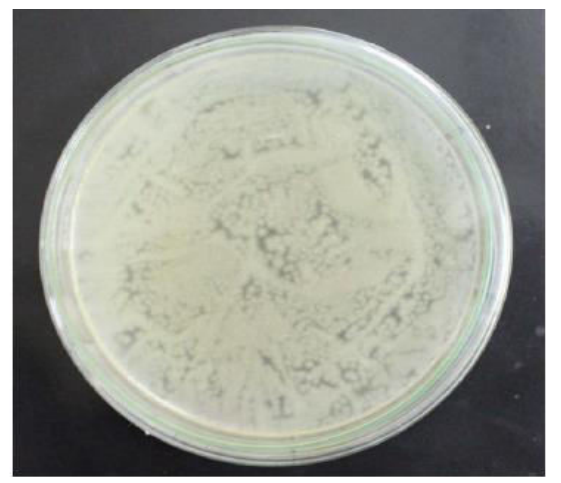

Fig. 2: Spread plate culture morphology of E. hirae on nutrient agar.

Enrichment of Artemia nauplii with E. hirae:

The brine shrimp, A. franciscana cyst was purchased from Aqua World, Paris Corner, Chennai, India. The cysts $(2 \mathrm{~g} / 20 \mathrm{~L}$ and $15 \mathrm{~g}$ $\mathrm{kg}^{-1}$ body biomass of the prawns) were taken and hydrated in $1 \mathrm{~L}^{-1}$ of purified artificial saltwater (prepared from artificial sea salt powder $35.0 \mathrm{~g} \mathrm{~L}^{-1}, \mathrm{pH}$ of 6.5 ) for 12-15 $\mathrm{h}$. The cysts burst and the embryo surrounded by the 
Table 1: Proximate compositions and mineral contents in the basal diet formulated

\begin{tabular}{|c|c|}
\hline Proximate composition & (\%) \\
\hline Crude protein & 46.79 \\
\hline Total Nitrogen-free extract & 32.21 \\
\hline Ether extract (Crude fat) & 6.19 \\
\hline Crude fiber & 1.33 \\
\hline Ash & 6.81 \\
\hline Moisture & 9.84 \\
\hline Gross energy & $4443 \mathrm{kcal} / \mathrm{kg}$ \\
\hline \multicolumn{2}{|c|}{ Minerals } \\
\hline Sand and silica (Acid insoluble ash) & 0.88 \\
\hline Calcium & 0.80 \\
\hline Phosphorus & 0.90 \\
\hline Iron & 0.11 \\
\hline Copper & 0.002 \\
\hline Salt & 0.58 \\
\hline
\end{tabular}

hatching membrane become visible for few hours. The brownish orange coloured nauplii came out. The $48 \mathrm{~h}$ old Artemia nauplii were filtered and transferred to $1 \mathrm{~L}$ capacity glass beaker. Five such groups were enriched with $4865 \times 10^{-1}, 3264 \times 10^{-3}, 2274 \times 10^{-5}, 1764 \times 10^{-}$ 7 and $1071 \times 10^{-9}$ concentrations of E. hirae for $1 \mathrm{~h}$. The Artemia nauplii were washed with freshwater and fed to M. rosenbergii PL.

Procurement and Acclimatization of $M$. rosenbergii PL:

The post larvae (PL-8) of $M$. rosenbergii were procured from a prawn hatchery, Marakkanam, Chennai, India. They were transported to the laboratory in polythene bags filled with oxygenated water and acclimatized with ground water


$0.94 \pm 0.05 \mathrm{~g} / \mathrm{L} ;$ DO $4.25 \pm 0.25 \mathrm{mg} / \mathrm{L}$; Salinity, $0.70 \pm 0.02 \mathrm{mg} / \mathrm{L} ; \quad \mathrm{EC}, \quad 1.01 \pm 0.01 \mathrm{Ms} / \mathrm{cm}$; Ammonia, $0.028 \pm 0.006 \mathrm{mg} / \mathrm{L}$ ) for two weeks in cement tanks. During acclimatization the prawns were fed with Artemia nauplii, boiled egg albumin threads and artificial feed formulated in our laboratory. Nearly half of the tank water was renewed every day and adequately aerated in order to maintain a healthy environment. The unfed feed, faecal material, exuvia/moults, and dead prawns if any were routinely removed by siphoning without disturbing the prawns while renewing the water medium.

Feeding Trail:

The feeding trials were conducted for a period of 45 days. Seven group of $M$. rosenbergii $(1.1 \pm 0.05 \mathrm{~cm} ; 0.05 \pm 0.003 \mathrm{~g})$ were taken. The group 1 was fed with artificial feed, group 2 was fed with unenriched Artemia nauplii, and groups 3-7 were fed with E. hirae $\left(4865 \times 10^{-1}\right.$, $3264 \times 10^{-3}, 2274 \times 10^{-5}, 1764 \times 10^{-7}, 1071 \times 10^{-9}$ ) enriched Artemia nauplii. Each group comprised of 30 individuals accommodated in $25 \mathrm{~L}$ of ground water. The water medium was renewed daily by siphoning and aerated. While renewing the water medium, the unfed feed, feces and moult were removed. At the end of the feeding trial the morphometric measurements were taken for calculating the nutritional indices and estimating concentrations of basic biochemical constituents, such as total protein, amino acid, carbohydrate and lipid, and activities of digestive enzymes, such as protease, amylase and lipase.

\section{Calculation of Nutritional Indices:}

The survival rate (SR), length gain (LG), weight gain (WG), and specific growth rate (SGR) were individually calculated (Tekinay and Davis, 2001).

Survival $(\%)=$ Total No. of live animals/Total No. of initial animals $\times 100$

Length gain $(\mathrm{cm})=$ Final length $(\mathrm{cm})-$ Initial length $(\mathrm{cm})$

Weight gain $(\mathrm{g})=$ Final weight $(\mathrm{g})$ - Initial weight (g)

Specific growth rate, $(\%)=\log \mathrm{W} 2-\log \mathrm{W} 1 / \mathrm{t} \times$ 100 
Where, W1 and W2 = Initial and Final weight, respectively $(\mathrm{g})$, and $\mathrm{t}=$ Total number of experimental days.

\section{Estimations of Basic Biochemical Constituents:}

The basic biochemical constituents, such as total protein, amino acid and carbohydrate were estimated in test prawns adopting standard methodologies (Lowry et al., 1951; Moore and Stein, 1948; Roe, 1955), respectively. The total lipid was extracted gravimetrically (Folch et al., 1957) and spectrophotometrically estimated (Barnes and Blackstock, 1973). The contents of ash and moisture were analysed (AOAC, 1995).

Assays of Digestive Enzymes Activities:

Activities protease, amylase and lipase were assayed on $45^{\text {th }}$ day of feeding trial. The digestive tract of prawns were carefully dissected out and homogenized in ice-cold distilled water and centrifuged at $9000 \mathrm{~g}$ under $4 \mathrm{C}$ for $20 \mathrm{~min}$. The supernatant was served as crude enzyme source. Total protease activity was determined by caseinhydrolysis method (Furne et al., 2005), where one unit of enzyme activity represented the amount of enzyme required to liberate $1 \mu \mathrm{g}$ of tyrosine per min. The specific activity of amylase was calculated as mg of maltose liberated per $\mathrm{g}$ of starch per hour (Bernfeld, 1955). Lipase activity was assayed and calculated as the amount of free fatty acid released from triacylglycerol per unit time (Furne et al., 2005).

\section{Gut Microbial Colonization:}

The bacterial culture was performed in the gut homogenate of experimental prawns fed with E. hirae $\left(1764 \times 10^{-7}\right)$. The prawns were deactivated by keeping them in freezer at -20 $\mathrm{C}$ for $10 \mathrm{~min}$. The surface of the prawn was sterilized with $50 \mathrm{ppm}$ formalin for 30 seconds for removing external flora. Then the digestive tract was dissected out and homogenized with phosphate buffered saline $(\mathrm{pH}, 7.2)$ under aseptic condition. The homogenate was serially diluted up to $10^{-7}$. The aliquot $(0.5 \mathrm{ml})$ was mixed with agar nutrient broth and incubated at $35 \mathrm{C}$ for $24 \mathrm{~h}$. The broth $(0.1 \mathrm{ml})$ was seeded on the surface of freshly prepared nutrient agar plate and incubated at $37 \mathrm{C}$ for $24 \mathrm{~h}$. Different bacterial colonies seen were identified and confirmed through routine bacteriological tests, such as Gram's staining, motility test, Indole test, methyl red test, Voges Proskauer test, citrate utilization test, starch hydrolases, gelatin hydrolases, nitrate reduction test, oxidase test, catalase test and carbohydrate fermentation test (Holt et al., 1996). The bacterial colony was enumerated by using the formula-- Bacterial count (CFU/g) = Number of colonies $\times$ Dilution factor/ Volume of sample (g).

\section{Statistical Analysis:}

All the data were subjected to statistical analysis through one-way ANOVA and subsequent post-hoc multiple comparisons (DMRT using SPSS v20). The $P$ value less than 0.05 (95\%) was considered as statistically significant.

\section{Results and Discussion}

Survival Rate and Nutritional Indices:

The survival rate (SR) and growth rate (WG and SGR) were found to be significantly $(P<0.05)$ higher at all concentrations $\left(4865 \times 10^{-1}, 3264 \times 10^{-3}, 2274 \times 10^{-5}, 1764 \times 10^{-7}\right.$, and $1071 \times 10^{-9}$ ) of E. hirae enriched Artemia nauplii fed PL when compared with unenriched Artemia and the PL fed with pelletized feed. Among these concentrations, 
$1764 \times 10^{-7}$ has produced the best growth performance (Fig. 3; Table 2).

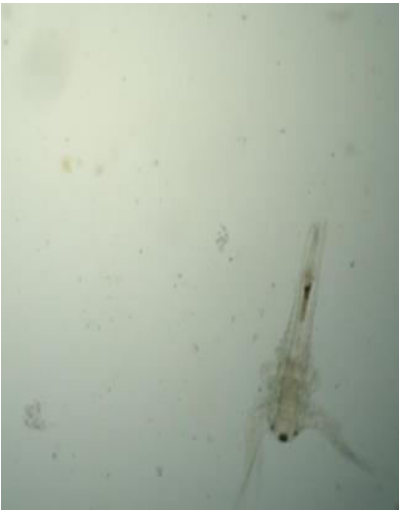

A

Fig. 3: A. franciscana nauplii (24 hrs., old). A: Unenriched; B: Enriched with E. hirae (CFU $\left.=1764 \times 10^{-7}\right)$.

The following studies support our result on growth and survival: in Angelfish, Pterophyllum scalare fed with Artemia nauplii enriched with symbiotic bacterium (Pediococcus acidilactici and fructooligosaccharide) (Mahmood et al., 2016); in M. rosenbergii fed with Lactobacillus sporogenes enriched Artemia, Binifit ${ }^{\mathrm{TM}}$, Bacillus. coagulans and Bacillus subtilis (Seenivasan et al., 2011, 2012, 2014; Karthik et al., 2018); in shrimp Litopenaeus vannamei fed with microencapsulated and freeze-dried Bacillus (Nimrat et al., 2012). Ranjit Kumar et al., (2017) reported that Bacillus licheniformis significantly reduced the cumulative mortality of $M$. rosenbergii challenged with Vibrio alginolyticus due to improved immunity. According to Liu et al. (2010), Bacillus sp., administration had increased survival rate of shrimp due to enhanced stress resistance. A significant increase in weight gain was reported in parrot fish fed with the diet containing Bacillus subtilis (Liu et al., 2018).
Activities of Digestive Enzymes and Contents of Basic Biochemical Constituents:

Activities of protease, amylase and lipase, and concentrations of total protein, amino acids, carbohydrate, and lipids were found to be significantly $(P<0.05)$ elevated in $E$. hirae enriched Artemia nauplii fed $M$. rosenbergii PL when compared with un-enriched Artemia and artificial pelletized feed. Among different concentrations of E. hirae, $1764 \times 10^{-7}$ produced the best performance (Table 3 ).

Bacillus sp. generally use a variety of nutrients for their growth and simultaneously release relevant digestive enzymes and other necessary growth factors that facilitate nutrient assimilation in their hosts resulting in prevention of intestinal disorders and higher growth and survival (Wang, 2007; Sahu et al., 2008; Lara-Flores, 2011). Activities of digestive enzymes of Penaeus vannamei larvae were significantly increased when using Bacillus coagulans in their feeding regime (Zhou et al., (2009). Some other studies also reported that probiotic bacteria could participate in the digestion processes by producing protease, amylase and lipase, as well as some necessary growth factors in the hosts (Arcllano and Olmos 2002; Wang and Xu 2006; Wang 2007; Motlagh et al., 2012). Some non-probiotic strains, such as genetically modified Escherichia coli, were also reported to be able to produce large amount of proteases and lipases, which could facilitate the digestive processes in Fenneropenaeus indicus post-larvae (Sirvas-Cornejo et al., 2007). An increased activity of digestive enzymes was reported in Penaeus vannamei when Bacillus coagulans SC8168 given even at the latter stages (Zhou et al., 2009). Enhanced protease activity was reported in Litopenaeus 
Table 2: Survival and growth of M. rosenbergii PL fed with pellet feed, un-enriched and E. hirae enriched Artemia nauplii for 45 days.

\begin{tabular}{|c|c|c|c|c|c|c|c|c|}
\hline \multirow[b]{2}{*}{ Parameter } & \multirow[b]{2}{*}{$\begin{array}{l}\text { Pelletized } \\
\text { feed }\end{array}$} & \multirow{2}{*}{$\begin{array}{l}\text { PL fed with } \\
\text { Un-enriched } \\
\text { Artemia } \\
\text { nauplii }\end{array}$} & \multicolumn{5}{|c|}{ PL fed with E. hirae enriched Artemia nauplii } & \multirow[b]{2}{*}{$\begin{array}{c}\text { F- } \\
\text { value }\end{array}$} \\
\hline & & & $\begin{array}{c}4865 \times 10^{-1} \\
\text { CFU }\end{array}$ & $\begin{array}{c}3264 \times 10^{-3} \\
\text { CFU }\end{array}$ & $\begin{array}{c}2274 \times 10^{-5} \\
\text { CFU }\end{array}$ & $\begin{array}{c}1764 \times 10^{-7} \\
\mathrm{CFU}\end{array}$ & $\begin{array}{c}1071 \times 10^{-9} \\
\mathrm{CFU}\end{array}$ & \\
\hline SR $(\%)$ & $71.77 \pm 1.92^{\mathrm{f}}$ & $76.66 \pm 3.37 \mathrm{e}$ & $81.11 \pm 5.10^{\mathrm{bc}}$ & $85.55 \pm 1.92^{\mathrm{ab}}$ & $88.88 \pm 1.92^{\mathrm{a}}$ & $90.00 \pm 3.33^{a}$ & $87.77 \pm 1.92^{\mathrm{a}}$ & 12.82 \\
\hline Length $(\mathrm{cm})$ & $1.33 \pm 0.06 \mathrm{~g}$ & $1.67 \pm 0.06^{\mathrm{f}}$ & $1.71 \pm 0.09 \mathrm{~d}$ & $1.83 \pm 0.07^{\mathrm{d}}$ & $2.61 \pm 0.10^{\mathrm{b}}$ & $3.25 \pm 0.14^{\mathrm{a}}$ & $2.19 \pm 0.21^{\mathrm{c}}$ & 94.08 \\
\hline Weight (g) & $0.49 \pm 0.07^{f}$ & $0.72 \pm 0.05^{\mathrm{e}}$ & $0.93 \pm 0.15^{\mathrm{cd}}$ & $1.06 \pm 0.14 \mathrm{bc}$ & $1.30 \pm 0.09 \mathrm{~b}$ & $1.44 \pm 0.14^{\mathrm{a}}$ & $1.14 \pm 0.22 \mathrm{bc}$ & 73.45 \\
\hline $\mathrm{LG}(\mathrm{cm})$ & $0.33 \pm 0.11 \mathrm{~g}$ & $0.66 \pm 0.11^{\mathrm{f}}$ & $0.71 \pm 0.16^{\mathrm{d}}$ & $0.83 \pm 0.13^{\mathrm{d}}$ & $1.61 \pm 0.09 \mathrm{~b}$ & $2.25 \pm 0.10^{\mathrm{a}}$ & $1.19 \pm 0.18^{\mathrm{c}}$ & 18.24 \\
\hline WG (g) & $0.45 \pm 0.06 \mathrm{~g}$ & $0.67 \pm 0.05^{\text {ef }}$ & $0.89 \pm 0.15^{\mathrm{cd}}$ & $1.02 \pm 0.14 \mathrm{bc}$ & $1.09 \pm 0.02 \mathrm{bc}$ & $1.39 \pm 0.14^{\mathrm{a}}$ & $1.25 \pm 0.09 \mathrm{ab}$ & 18.54 \\
\hline SGR (\%) & $2.65 \pm 0.06^{\mathrm{e}}$ & $2.81 \pm 0.09 \mathrm{~cd}$ & $2.93 \pm 0.16^{\mathrm{sb}}$ & $2.99 \pm 0.14^{\mathrm{ab}}$ & $3.01 \pm 0.15^{\mathrm{ab}}$ & $3.12 \pm 0.13^{a}$ & $3.08 \pm 0.12^{b}$ & 4.77 \\
\hline
\end{tabular}

Initial morphometric data: $1.1 \pm 0.05 \mathrm{~cm}$ length; $0.05 \pm 0.006 \mathrm{~g}$ weight.

Each value represents mean \pm SD of three individual observations.

Mean values within the same row sharing different alphabetical letter superscripts are statistically significant at $\mathrm{P}<0.05$ (one-way ANOVA and subsequent post hoc multiple comparison with DMRT).

SR, survival rate; LG, length gain; WG, weight gain, SGR, specific growth rate

Table 3: Concentrations of biochemical constituents and activities of digestive enzymes in M. rosenbergii PL fed with pelletized feed, un-enriched and E. hirae enriched Artemia nauplii for 45 days.

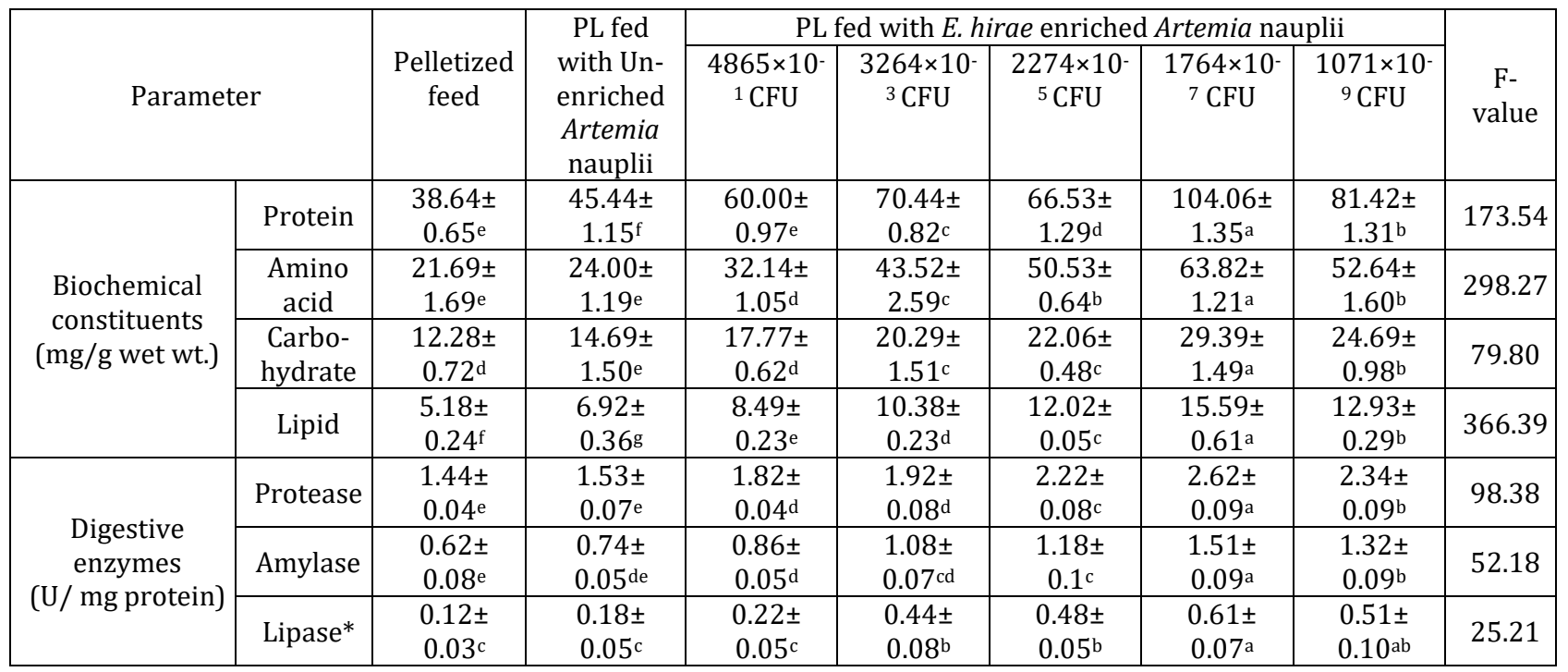

Each value represents mean \pm standard deviation of three individual observations. ${ }^{*}$, unit $\times 10^{3}$

Mean values within the same row sharing different alphabetical letter superscripts are statistically significant at $\mathrm{P}<0.05$ (one-way ANOVA and subsequent post hoc multiple comparison with DMRT 
vannamei fed with Bacillus subtilis E20 (Liu et al., 2009).

An increase in total protein, free amino acid, total carbohydrate, total lipids and ash contents in $M$. rosenbergii $\mathrm{PL}$ has been reported when $L$. sporogenes incorporated diet was given (Seenivasan et al., 2014). Similarly, Jayanthi et al. (2015 a, b) reported that concentrations of total protein, carbohydrate and lipid were increased in Lactobasil ${ }^{\circledR}$ plus incorporated feed fed $M$. rosenenbergii PL. Fernandez et al. (2011) reported that Lactic acid bacteria enhanced the crude protein and ash content in juveniles of Penaeus indicus.

Probiotics have been reported to increase intestinal enzyme activities and thus improve nutrient digestibility and food absorption in pearl spot Etropus suratensis and tilapia Oreochromis mossambicus (Sankar et al., 2016) and narrow clawed crayfish Astacus leptodactylus Eschscholtz (Valipour et al., 2019). It has been reported that Lactobacillus pentosus improved growth performance due to increased activities of digestive enzymes in Litopenaeus vannamei (Zhen and Wang, 2016). Addition of Lactobacillus delbrueckii as feed additive has significantly improved lipase activity in common carp (Zhang et al., 2018). Probiotics have the ability to modulate gut microbiota and subsequently improve digestive enzymes secretion which in turn improves digestion and feed utilization -- in white shrimp, Litopenaeus vannamei by using Bacillus coagulans (Wang et al., 2012) and Bacillus subtilis (Zokaeifar et al., 2012); using amylolitic bacteria as candidates of probiotics in tilapia, Oreochromis sp. (Putra et al., 2015); in snakehead, Channa argus using Bacillus amyloliquefaciens (Dai et al., 2018). It has been reported that an increased protein, fat and total digestibility in catfish (Clarias sp.) positively correlated to final weight, weight gain, PER, and SGR (Afrilasari et al., 2016). Similar results were reported in white shrimp Litopenaeus vannamei that Bacillus subtilis in its feed has increased crude protein digestibility, crude lipid digestibility and dry matter apparent digestibility (Tsai et al., 2019). The bacteria, live feeds and their extracellular/exogenous enzymes could boost the production of endogenous enzymes (protease, lipase, and cellulase) in animals including fish and shrimp, which further enhance feed utilization and growth performance-- in Japanese sardine, Sardinops melanotictus by feeding rotifer (Kurokawa et al., 1998) and wild mixed zooplankton (Manickam et al., 2020); in Indian white shrimp, Fenneropenaeus indicus by giving Bacillus sp. (Ziaei-Nejad et al., 2006); in Penaeus vannamei by giving Bacillus coagulans (Zhou et al., 2009).

Analysis of Gut Microbial Consortium:

Aquatic animals are monogastric and have difficulty in digesting complex or fibrous feedstuffs de facto, thus bacteria colonized in the gut enhanced secretion of digestive enzymes in the larval stage to help them to expedite the digestion on the foodstuffs to be more effective at later stages (Ronnestad et al., 2003; Dawood and Khosio, 2016). This mechanism is of particularly important during the weaning stages due to low level of enzyme production in the early life of fishes and prawns. This has been studied in Roach, Rutilus rutilus, where presence of Aeromonas, Pseudomonas, Enterobacteriaceae, Flavobacterium, Micrococcus and Acinetobacter were identified (Skrodenyte-Arbaciauskiene, 2007). 
The presence of Escherichia coli, Klebsiella sp., Citrobacter sp., Acetinobacter sp., Streptococcus sp., Bacillus sp., Staphylococcus sp. and Pseudomonas sp. were identified through colony morphology and biochemical tests in the gut of un-enriched Artemia fed PL. In the gut of experimental PL fed with $1764 \times 10^{-7}$ concentration of E. hirae enriched Artemia produced the presence of Enterococcus sp., Escherichia coli, Lactobacillus sp., Acinetobacter and Staphylococcus sp. which were identified through colony morphology and biochemical tests. Thus, in this study, Klebsiella sp., Citrobacter sp., Streptococcus sp., and Pseduomonas sp. were competitively excluded by colony establishment of Enterococcus sp. in experimental PL (Figs. 4, 5; Tables 4, 5).

Bacterial antagonism is a common phenomenon in nature; therefore, microbial interactions play a major role in the equilibrium between competing beneficial and potentially pathogenic microorganisms. However, the composition of microbial communities can be altered by husbandry practices and environmental conditions that stimulate the proliferation of selected bacterial species. It is well known that the microbiota in the gastrointestinal tract of aquatic animals can be modified, for example by ingestion of other microorganisms; therefore, microbial manipulation constitutes a viable tool to reduce or eliminate the incidence of opportunist pathogens (Balcazar, 2002).

Probiotics are excellent source of growth promoter and provide vast nutritional benefits, among them the genera of Bacillus could biosynthesize a wide range of extracellular enzymes such as protease, lipase, amylase and cellulose and other growth

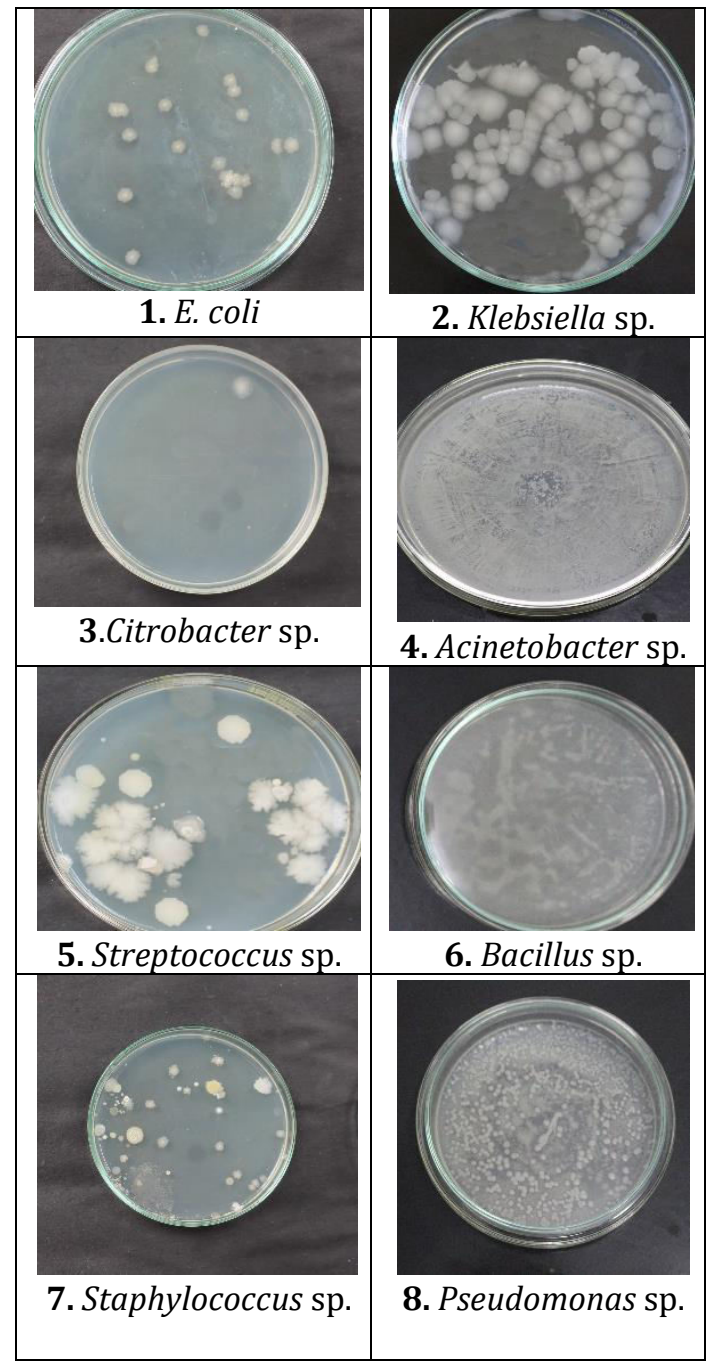

Fig. 4: Agar plate morphology of different bacterial culture from the gut of $M$. rosenbergii PL fed with un-enriched Artemia nauplii.

factors such as biotin, vitamin $\mathrm{B}_{12}$, short-chain fatty acids, and essential amino acids. Therefore Bacillus sp. enhanced the growth of Penaeus monodon when supplemented with diet (De et al., 2018). The usage of Bacillus sp. (B. thuringiensis, B. megaterium, B. polymyxa, $B$. licheniformis and B. subtilis) and Yeast enhanced microbiota, promote survival and growth of Litopenaeus vannamei juveniles (Nimrat et al., 2019). Bacillus sp. when used as probiotics were able to inhibit pathogens by colonizing both the culture water and the shrimp digestive tract to exclude other harmful bacteria in Penaeus monodon and 
Table 4: Confirmative results of biochemical tests for micro flora present in the gut of M. rosenbergii PL fed with $1764 \times 10^{-7} \mathrm{CFU}$ of E.hirae enriched Artemia nauplii.

\begin{tabular}{|c|c|c|c|c|c|c|c|c|c|c|c|c|c|c|}
\hline \multirow{2}{*}{ Test } & \multirow[b]{2}{*}{ Eh } & \multicolumn{8}{|c|}{ Un-enriched Artemia nauplii fed PL gut } & \multicolumn{5}{|c|}{$\begin{array}{l}\text { E. hirae enriched Artemia nauplii fed PL } \\
\text { gut }\end{array}$} \\
\hline & & $E c$ & $\begin{array}{r}K \\
\text { sp. }\end{array}$ & $\begin{array}{r}C \\
\text { sp. }\end{array}$ & $\begin{array}{c}A \\
\text { sp. }\end{array}$ & $\begin{array}{l}\text { Ste } \\
\text { sp. }\end{array}$ & $\begin{array}{l}B \\
\mathrm{sp} .\end{array}$ & $\begin{array}{c}\text { Sta } \\
\text { sp. }\end{array}$ & $\begin{array}{c}P \\
\text { sp. }\end{array}$ & $E$ sp. & Ec & $\begin{array}{c}\mathrm{L} \\
\mathrm{sp}\end{array}$ & $\begin{array}{c}A \\
\text { sp. }\end{array}$ & $\begin{array}{l}\text { Sta } \\
\text { sp. }\end{array}$ \\
\hline Gram's staining & + & - & - & - & + & + & + & + & - & + & + & + & - & + \\
\hline Motility test & - & + & - & + & + & - & + & - & + & - & - & + & + & + \\
\hline Indole test & - & + & - & - & + & - & - & - & - & - & - & - & - & - \\
\hline Methyl red test & - & + & - & + & - & - & - & + & - & - & - & - & + & - \\
\hline Vp test & + & - & + & - & - & - & + & + & - & + & + & - & - & + \\
\hline $\begin{array}{l}\text { Citrate utilization } \\
\text { test }\end{array}$ & - & - & + & + & + & + & + & + & + & - & - & - & + & + \\
\hline Starch hydrolases & - & + & - & - & - & + & + & + & - & - & - & + & - & + \\
\hline Gelatin hydrolases & - & + & - & - & - & + & + & + & + & + & - & + & - & + \\
\hline $\begin{array}{c}\text { Nitrate reduction } \\
\text { test }\end{array}$ & + & + & + & + & + & + & + & + & + & + & + & + & + & + \\
\hline Oxidase test & - & + & - & - & - & - & - & - & + & - & - & - & - & - \\
\hline Catalase test & - & - & + & + & + & - & + & + & + & - & - & + & + & + \\
\hline Glucose test & $\mathrm{A}$ & A & $\mathrm{A}$ & $\mathrm{A}$ & $\mathrm{A}$ & $\mathrm{A}$ & $\mathrm{A}$ & $\mathrm{A}$ & $\mathrm{A}$ & $\mathrm{A}$ & $\mathrm{A}$ & $\mathrm{A}$ & $\mathrm{A}$ & $\mathrm{A}$ \\
\hline Lactose test & $\mathrm{A}$ & $\mathrm{A}$ & $\mathrm{A}$ & $\mathrm{A}$ & $\mathrm{NA}$ & NA & $\mathrm{NA}$ & $\mathrm{A}$ & NA & $\mathrm{A}$ & $\mathrm{A}$ & $\mathrm{A}$ & $\mathrm{A}$ & NA \\
\hline Sucrose test & $\mathrm{A}$ & $\mathrm{A}$ & $\mathrm{A}$ & $\mathrm{A}$ & NA & $\mathrm{A}$ & $\mathrm{A}$ & $\mathrm{A}$ & $\mathrm{A}$ & $\mathrm{A}$ & $\mathrm{A}$ & $\mathrm{A}$ & $\mathrm{A}$ & $\mathrm{A}$ \\
\hline Manitol test & $\mathrm{A}$ & $\mathrm{A}$ & $\mathrm{A}$ & $\mathrm{A}$ & NA & $\mathrm{A}$ & $\mathrm{A}$ & $\mathrm{A}$ & $\mathrm{A}$ & NA & $\mathrm{A}$ & $\mathrm{A}$ & $\mathrm{A}$ & $\mathrm{A}$ \\
\hline Maltose test & $\mathrm{A}$ & NA & $\mathrm{A}$ & $\mathrm{A}$ & NA & NA & $\mathrm{A}$ & NA & $\mathrm{A}$ & $\mathrm{A}$ & $\mathrm{A}$ & $\mathrm{A}$ & $\mathrm{A}$ & $\mathrm{A}$ \\
\hline
\end{tabular}

+, Positive; -, Negative; A, Acid production; NA, No acid production; Eh, Enterococcus hirae; Ec, Escherichia coli; K sp., Klebsiella sp.; C sp., Citrobacter sp.; A sp., Acetinobacter sp.; Ste sp., Streptococcus sp.; B sp., Bacillus sp.; Sta sp., Staphylococcus sp.; P sp., Pseudomonas sp.; E sp., Enterococcus sp.; L sp., Lactobacillus sp.



Fig. 5: Agar plate morphology of different bacterial culture from the gut of M. rosenbergii PL fed with E. hirae (CFU $=1764 \times 10^{-7}$ ) enriched Artemia nauplii. 
Table 5: Bacterial consortium in the gut of $M$. rosenbergii PL fed with un-enriched and $1764 \times 10^{-7} \mathrm{CFU}$ of $E$. hirae enriched Artemia nauplii.

\begin{tabular}{|c|c|c|}
\hline Samples & Identified species & $\begin{array}{c}\text { Composition } \\
(\%)\end{array}$ \\
\hline \multirow{9}{*}{$\begin{array}{l}\text { Un- } \\
\text { enriched } \\
\text { Artemia } \\
\text { nauplii } \\
\text { fed PL } \\
\text { gut }\end{array}$} & E. coli & 10 \\
\hline & Klebsiella sp., & 8 \\
\hline & Citrobacter sp., & 15 \\
\hline & Acinetobacter sp., & 12 \\
\hline & Streptococcus sp., & 11 \\
\hline & Bacillus sp., & 18 \\
\hline & $\begin{array}{l}\text { Staphylococcus } \\
\text { sp., }\end{array}$ & 10 \\
\hline & Pseduomonas sp., & 11 \\
\hline & Total & 93 \\
\hline \multirow{6}{*}{$\begin{array}{l}\text { E. hirae } \\
\text { enriched } \\
\text { Artemia } \\
\text { nauplii } \\
\text { fed PL } \\
\text { gut }\end{array}$} & Enterococcus sp., & 34 \\
\hline & E. coli & 21 \\
\hline & Lactobacillus sp., & 18 \\
\hline & Acinetobacter sp., & 8 \\
\hline & $\begin{array}{l}\text { Staphylococcus } \\
\text { sp., }\end{array}$ & 7 \\
\hline & Total & 88 \\
\hline
\end{tabular}

Penaeus vannamei, producing an anti-bacterial substance or activating both cellar and humoral immune defences in shrimp (Rengpipat et al., 1998; Mariel et al., 2004). Bacillus subtilis and Bacillus licheniformis improved survival, growth and feed utilization efficiency of Litopenaeus vannamei after feeding with diets (Madani et al., 2018). Bacillus sp., and Enterococcus faecalis improved growth performance in Litopenaeus vannamei (Guzmán-Villanueva et al., 2019). Bacillus subtilis activating the immunity of white shrimp, Litopenaeus vannamei and improves shrimp health (Chien et al., 2020). Supplementation of Bacillus subtilis has improved the growth performance, immune response and antioxidant activities in Litopenaeus vannamei (Shen et al., 2010). Thus, Bacillus spp. have served as promising probiotics, able to inhibit colonization of prospective pathogens in the intestine of shrimp, thereby boosting shrimp immunity and disease resistance. Competitive exclusion of potential pathogenic bacteria effectively reduces or eliminates the need for antibiotic prophylaxis. For example, Vibrio alginolyticus has also been used to increase survival and growth of Litopenaeus vannamei PL (Garriques and Arevalo, 1995).

\section{Conclusion}

In this study, E. hirae got colonized in the gut of $M$. rosenbergii, eliminated Klebsiella sp., Citrobacter sp., Streptococcus sp. and Pseduomonas sp. and enhanced the survival and growth of the host. Therefore, it can be taken as a probiotic bacterium to maintain sustainability in prawn culture.

\section{Acknowledgement}

The authors gratefully acknowledge Bharathiar University, Coimbatore, India for providing laboratory facility.

\section{References}

Afrilasari W, Widanarni and Meryandini A. (2016) Effect of Probiotic Bacillus megaterium PTB 1.4 on the population of intestinal microflora, digestive enzyme activity and the growth of catfish (Clarias sp.). HAYATI J. Biosci. 23: 168-172.

Ahmed MO and Baptiste KE. (2018) Vancomycinresistant Enterococci: A review of antimicrobial resistance mechanisms and perspectives of human and animal health. Microb. Drug Resist. 24: 590-606.

Al-Dohail MA, Hashim R and Aliyu-Paiko M. (2009) Effects of the probiotic Lactobacillus acidophilus on the growth performance, haematology parameters and immunoglobulin concentration in African catfish (Clarias gariepinus, Burchell 1822) fingerling. Aquac. Res. 40: 1642-1652.

AOAC (1995). Official methods of analysis of association of analytical communities international. 2 vol. $16^{\text {th }}$ ed. Arlington, VA, USA.

Apines-Amar MJS and Amar EC. (2015) Use of immunostimulants in shrimp culture: research signpost Kerala India: Biotechnological Advances in Shrimp Health Management in the Philippines, pp. 45-71. 
Arcllano CF and Olmos SJ. (2002) Thermostable a-1,4and a-1,6- glucosidase enzymes from Bacillus sp. isolated from a marine environment. World J. Microb. Biot. 18:791-795.

Balcazar JL. (2002) Use of probiotics in aquaculture: general aspects. In: de Blas, I. (Ed.), Memoriasdel Primer Congreso Iberoamericano Virtual de Acuicultura, Zaragoza, Spain, pp. 877-881.

Barman D, Nen P, Mandal SC and Kumar V. (2013) Aquaculture health management: A new approach. J. Marine Sci. Res. Dev. 3: 1-11.

Barnes H and Blackstock J. (1973) Estimation of lipids in marine animals and tissues. Detail investigation of the sulpho-phosphor-vanillin method for total lipids. J. Exp. Mar. Biol. Ecol. 12: 103-118.

Bernfeld P. (1955) Amylases. In: Methods in Enzymology, eds. Colowick SP. and Kaplan NO., Academic Press, New York, pp. 149-158.

Boss R, Overesch G and Baumgartner A. (2016) Antimicrobial resistance of Escherichia coli, Enterococci, Pseudomonas aeruginosa, and Staphylococcus aureus from raw fish and seafood imported into Switzerland. J. Food Prot. 79: 12401246.

Cai YM, Suyanandana P, Saman and Benno Y. (1999) Classification and characterization of lactic acid bacteria isolated from the intestine of common carp and freshwater prawns. J. Gen. Appl. Microbiol. 45: 177-184.

Chen CY, Chen PC, Weng FCH, Shaw GTW and Wang D. (2017) Habitat and indigenous gut microbes contribute to the plasticity of gut microbiome in oriental river prawn during rapid environmental change. Plos One 12: e0181427.

Chien CC, Lin TY, Chi CC and Liu CH. (2020) Probiotic, Bacillus subtilis E20 alters the immunity of white shrimp, (Litopenaeus vannamei) via glutamine metabolism and hexosamine biosynthetic pathway. Fish Shellfish Immunol. 98:176-185.

Dai B, Hou Y, Hou Y and Qian L. (2018) Effects of multienzyme complex and probiotic supplementation on the growth performance, digestive enzyme activity and gut microorganisms composition of snakehead (Channa argus). Aquac. Nutr. 25: 15-25.

Dawood MAO and Koshio S. (2016) Recent advances in the role of probiotics and prebiotics in carp aquaculture: A review. Aquac. 454: 243-251.

De D, Raja RA, Ghoshal TK, Mukherjee S and Vijayan KK. (2018) Evaluation of growth, feed utilization efficiency and immune parameters in tiger shrimp
(Penaeus monodon) fed diets supplemented with or diet fermented with gut bacterium Bacillus sp. DDKRC1. Isolated from gut of asian seabass (Lates calcarifer). Aquac. Res. 49: 2147-55.

Devriese LA, Van De, Kerckhove A, Kilpper-BälzR and Schleifer KH. (1987) Characterization and identification of Enterococcus species isolated from animals. Int. J. Syst. Evol. Micr. 37: 257-259.

FAO (2016). The state of world fisheries and aquaculture (SOFIA): Contributing to food security and nutrition for all, Rome: Food and Agriculture Organization. pp. 200.

Farzanfar A. (2006) The use of probiotics in shrimp aquaculture. Pathogens and Disease 48: 149-158.

Fernandez R, Sridhar M and Sridhar N. (2011) Effect of lactic acid bacteria administered orally on growth performance of (Penaeus indicus) (H. Milne Edwards) juveniles. Res. J. Microbiol. 6: 466-479.

Folch J, Lees M and Bloane-Stanely GH. (1957) A simple method for the isolation and purification of total lipids from animal tissues. J. Biol. Chem. 266: 497-509.

Furne M, Hidalgo MC, Lopez A, Garcia Gallego M, Morales AE and Domezain A. (2005) Digestive enzyme activities in Adriatic sturgeon (Acipenser naccarii) and rainbow trout (Oncorhynchus mykiss), A comparative study. Aquac. 250: 391-398.

Garriques D and Arevalo G. (1995) An evaluation of the production and use of a live bacterial isolate to manipulate the microbial flora in the commercial production of (Penaeus vannamei) post larvae in Ecuador. In: Swimming Through Troubled Waters. Proceedings of the Special Session on Shrimp Farming (ed. Browd C.L. and Hopkins J.S.), World Aquaculture Society, Baton Rouge, USA.pp. 53-59.

Geng X, Dong XH, Tan BP, Yang QH, Chi SY, Liu HY and Liu XQ. (2012) Effects of dietary probiotic on the growth performance, non-specific immunity and disease resistance of cobia (Rachycentron canadum). Aquac. Nutr. 18: 46-55.

Ghosh AK, Bir J, Azad MAK, Hasanuzzaman AFM, Islam MS and Huq KA. (2016) Impact of commercial probiotics application on growth and production of giant fresh water prawn (Macrobrachium rosenbergii DeMan, 1879). Aquacult. Rep. 4: 112117.

Guzman-Villanueva LT, Escobedo-Fregoso C, BarajasSandoval DR, Gomez-Gil B, Pena-Rodríguez A, Martínez-Diaz SF and Quiroz-Guzman E. (2019) Assessment of microbial dynamics and antioxidant enzyme gene expression following probiotic administration in farmed Pacific white shrimp 
(Litopenaeus vannamei). Aquac. 519: 734907. doi:10.1016/j.aquaculture.2019.734907.

Holt JG, Krie NR, Sneath PHA, Stately JT and Williams ST. (1996) Bergey's Manual of Determinative Bacteriology, $9^{\text {th }}$ ed. Baltimore, Williams and Wilkins. p.787.

Jayanthi L, Bhavan PS, Srinivasan V, Muralisankar T and Manickam N. (2015 a) Probiotics product (LactoBacil ${ }^{\circledR}$ plus) on improvement of survival, growth, digestive enzymes activity, nutritional status and gut microflora of the prawn (Macrobrachium rosenbergii). Int. J. Curr. Res. 7: 11440-11453.

Jayanthi L, Bhavan PS, Srinivasan V, Muralisankar T and Manickam N. (2015 b) Dietary supplementation of probiotics product (ViBact*) on the survival, growth, biochemical constituents and gut microflora of the giant freshwater prawn (Macrobrachium rosenbergii) post-larvae. Asian J. Biochem. Pharm. Res. 2: 67-88.

Karthik M, Bhavan PS and Manjula T. (2018) Growth promoting potential and colonization ability of probiotics (Bacillus coagulans and Bacillus subtilis) on the freshwater prawn (Macrobrachium rosenbergii) post-larvae. Insights Biol. Med. 2: 7-18.

Kurekci C, Onen SP, Yipel M, Aslantas O and Gundogdu A. (2016) Characterisation of phenotypic and genotypic antibiotic resistance profile of Enterococci from cheeses in Turkey. Korean J. Food Sci. An. 36: 352-358.

Kurokawa T, Shiraishi M and Suzuki T. (1998) Quantification of exogenous protease derived from zooplankton in the intestine of Japanese sardine (Sardinops melanotictus) larvae. Aquac. 161: 491-499.

Lara-Flores M. (2011) The use of probiotic in aquaculture: An overview. Int. Res. J. Microbiol. 2: 471- 478.

Liu CH, Chiu CS, Ho PL and Wang SW. (2009) Improvement in the growth performance of white shrimp (Litopenaeus vannamei), by a proteaseproducing probiotic Bacillus subtilis E20, from natto. J. Appl. Microbiol. 107: 1031-1041.

Liu $\mathrm{CH}, \mathrm{Wu} \mathrm{K}$, Chu TW and Wu TM. (2018) Dietary supplementation of probiotic, Bacillus subtilis E20, enhances the growth performance and disease resistance against Vibrio alginolyticus in parrot fish (Oplegnathus fasciatus). Aquac. Int. 26: 63-74.

Liu H, Liu M, Wang B, Jiang K, Jiang S, Sun S and Wang L. (2010) PCR-DGGE analysis of intestinal bacteria and effect of Bacillus sp. on intestinal microbial diversity in kuruma shrimp (Marsupenaeus japonicus). Chin. J. Oceanol. Limn. 28: 808-814.

Lowry OH, Rosebrough WJ, Fair AL and Randall RJ. (1951) Protein measurement with the Folin phenol reagent. J. Biol. Chem. 193: 265-275.

Madani NSH, Adorian TJ, Farsani HG and Hoseinifar SH. (2018) The effects of dietary probiotic Bacilli (Bacillus subtilis and Bacillus licheniformis) on growth performance, feed efficiency, body composition and immune parameters of white leg shrimp (Litopenaeus vannamei) post-larvae. Aquac. Res. 49: 1926-1933.

Mahmood A, Saeed M, Nasrollah A and Seyed HH. (2016) The effects of feeding with symbiotic (Pediococcus acidilactici and fructo-oligosaccharide) enriched adult Artemia on skin mucus immune responses, stress resistance, intestinal microbiota and performance of angelfish (Pterophyllum scalare). Fish Shellfish Immun. 54: 516-522.

Manickam N, Bhavan PS, Santhanam $P$ and Muralisankar T. (2020) Influence of wild mixed zooplankton on growth and muscle biochemical composition of the freshwater prawn Macrobrachium rosenbergii post-larvae. Aquac. 522. doi.org/10.1016/j.aquaculture.2020.735110 735110.

Mariel G, Fabiano T and Jenny R. (2004) Selection of probiotic bacteria and study of their immunostimulatory effect in Penaeus vannamei. Aquac. 233: 1-14.

Mathipa MG and Thantsha MS. (2017) Probiotic engineering: Towards development of robust probiotic strains with enhanced functional properties and for targeted control of enteric pathogens. Gut Pathogens. 9: 28.

Moore S and Stein WH. (1984) Methods in enzymol (Eds: Olowick, Spand Kalpan, ND) Academic Press New York. pp. 468.

Motlagh HRZ, Farhangi M, Rafiee G and Noori F. (2012) Modulating gut microbiota and digestive enzyme activities of Artemia urmiana by administration of different levels of Bacillus subtilis and Bacillus licheniformis. Aquac. Int. 20: 693-705.

Nadella RK, Prakash RR, Dash G, Ramanathan SK, Kuttanappilly LV and Mothadaka MP. (2017) Histopathological changes in giant freshwater prawn (Macrobrachium rosenbergii) (De Man 1879) fed with probiotic Bacillus licheniformis upon challenge with Vibrio alginolyticus. Aquac. Res. 49: 81-92.

Nimrat S, Suksawat S, Boonthai T and Vuthiphandchai V. (2012) Potential Bacillus probiotics enhance bacterial numbers, water quality and growth during 
early development of white shrimp (Litopenaeus vannamei). Vet. Microbiol. 159: 443-450.

Nimrat S, Khaopong W, Sangsong J, Boonthai $\mathrm{T}$ and Vuthiphandchai V. (2019) Dietary administration of Bacillus and yeast probiotics improves the growth, survival, and microbial community of juvenile white leg shrimp, (Litopenaeus vannamei). J. Appl. Aquac. 1-17.

Ninawe AS and Selvin J. (2009) Probiotics in shrimp aquaculture: Avenues and challenges. Critical Reviews Microbiol. 35: 43-66.

Putra AN and Widanarni. (2015) Screening of amylolitic bacteria as candidates of probiotics in tilapia (Oreochromis sp.). Res. J. Microbiol. 10: 1-13.

Rengpipat S, Phianphak W, Piyatiratitivorakul S and Menasveta P. (1998) Effects of a probiotic bacterium on black tiger shrimp (Penaeus monodon) survival and growth. Aquac. 167: 301-313.

Roe JH. (1995). The determination of sugar and blood and spinal fluid with anthrone reagent. J. Biol. Chem. 212: 335-343.

Ronnestad I, Tonheim SK, Fyhn HJ, Rojas-Garcia CR, Kamisaka Y, Koven W, Finn RN, Terjesen BF, Barr Y and Conceicao LEC. (2003) The supply of amino acids during early feeding stages of marine fish larvae: A review of recent findings. Aquac. 227: 147-164.

Sahu MK, Swarnakumar NS, Sivakumar K, Thangaradjou $\mathrm{T}$ and Kannan L. (2008) Probiotics in aquaculture: importance and future perspectives. Indian $\mathrm{J}$. Microbiol. 48: 299-308.

Sankar H, Philip B, Philip R and Singh ISB. (2016) Effect of probiotic on digestive enzyme activities and growth of cichlids, pearl spot (Etropus suratensis) and tilapia (Oreochromis mossambicus). Aquac. Nutr. 23: 852-864.

Seenivasan C, Bhavan PS and Radhakrishnan S. (2011) Effect of probiotics (Binifit ${ }^{T M}$ ) on survival, growth, biochemical constituents and energy budget of the freshwater prawn (Macrobrachium rosenbergii) post larvae. Elixir Aquac. 41: 5919-5927.

Seenivasan C, Bhavan PS, Radhakrishnan S and Shanthi R. (2012) Enrichment of Artemia nauplii with Lactobacillus sporogenes for enhancing the survival, growth and levels of biochemical of constituents in the post-larvae of freshwater prawn (Macrobrachium rosenbergii).Turk. J. Fish Aquat. Sc. 12: 23-31.

Seenivasan C, Radhakrishnan S, Shanthi R, Muralisankar $\mathrm{T}$ and SaravanaBhavan P. (2014) Effect of Lactobacillus sporogenes on survival, growth, biochemical constituents and energy utilization of freshwater prawn (Macrobrachium rosenbergii) post-larvae. J. Basic Appl. Zool. 67: 19-24.

Shen WY, Fu LL, Li WF and Zhu YR. (2010) Effect of dietary supplementation with Bacillus subtilis on the growth, performance, immune response and antioxidant activities of the shrimp (Litopenaeus vannamei). Aquac. Res. 41: 1691-1698.

Sirvas-Cornejo S, Latchford JW and Jones DA. (2007) Effect of microencapsulated diets supplemented with genetically modified bacteria on the growth and survival of (Fenneropenaeus indicus) postlarvae. Aquac. Nutr. 13:10-16.

Skrodenyte-Arbaciauskiene V. (2007) Enzymatic activity of intestinal bacteria in roach Rutilus rutilus L. Fish. Res. 73: 964-966.

Sun YZ, Yang HL, Ma RL and Lin WY. (2010) Probiotic applications of two dominant gut Bacillus strains with antagonistic activity improved the growth performance and immune responses of grouper (Epinephelus coioides). Fish Shellfish Immun. 29: 803-809.

Suzer C, Coban D, Okan-Kamaci H, Saka S, Firat K, Otgucuoglu $\mathrm{O}$ and Kucuksari H. (2008) Lactobacillus sp. bacteria as probiotics in gilthead sea bream (Sparus aurata, L.) larvae: Effects on growth performance and digestive enzyme activities. Aquac. 280: $140-145$.

Tekinay AA and Davies SJ. (2001) Dietary carbohydrate level influencing feed intake, nutrient utilisation and plasma glucose concentration in the rainbow trout (Oncorhynchus mykiss Walbaum, 1792). Turk. J. Vet. Anim. Sci. 25: 657-666.

Tsai CY, Chi CC and Liu CH. (2019) The growth and apparent digestibility of white shrimp (Litopenaeus vannamei), are increased with the probiotic, Bacillus subtilis. Aquac. Res. 50: 1475-1481.

Valipour A, Nedaei S, Noori A, Khanipour AA and Hoseinifar SH. (2019) Dietary Lactobacillus plantarum affected on some immune parameters, air exposure stress response, intestinal microbiota, digestive enzyme activity and performance of narrow clawed crayfish (Astacus leptodactylus, Eschscholtz). Aquac. 504: 121-130.

Verschuere L, Rombaut G, Sorgeloos P and Verstraete W. (2000) Probiotic bacteria as biological control agents in aquaculture. Microbiol. Mol. Biol. R.64: 655-671.

Wang YB. (2007) Effect of probiotics on growth performance and digestive enzyme activity of the shrimp (Penaeus vannamei). Aquac. 269: 259-264. 
Wang YB, Fu LL and Lin J. (2012) Probiotic (Bacillus coagulans) cells in the diet benefit the white shrimp (Litopenaeus vannamei). J. Shellfish Res. 31: 855-860.

Wang YB and Xu Z. (2006) Effect of probiotics for common carp (Cyprinus carpio) based on growth performance and digestive enzyme activities. Anim. Feed Sci. Tech. 127: 283-292.

Zai AS, Ahmad S and Rasool SA. (2009) Bacteriocin production by indigenous marine catfish associated Vibrio spp. Pak. J. Pharm. Sci. 22: 162-167.

Zhang C, Zhang J, Fan W, Huang M and Liu M. (2018) Effects of dietary Lactobacillus delbrueckii on growth performance, body composition, digestive and absorptive capacity, and gene expression of common carp (Cyprinus carpio Huanghe var). Aquac. Nutr. 25: 166-175.

Zheng CN and Wang W. (2016) Effects of Lactobacillus pentosus on the growth performance, digestive enzyme and disease resistance of white shrimp (Litopenaeus vannamei) (Boone, 1931). Aquac. Res. 48: 1-11.

Zhou XX, Wang YB and Li WF. (2009) Effect of probiotic on larvae shrimp (Penaeus vannamei) based on water quality, survival rate and digestive enzyme activities. Aquac. 287: 349-353.

Ziaei-Nejad S, Rezaei MH, TakamiGA, Lovett DL, Mirvaghefi AR and Shakouri M. (2006) The effect of Bacillus sp. bacteria used as probiotics on digestive enzyme activity, survival and growth in the Indian white shrimp (Fenneropenaeus indicus). Aquac. 252: 516-524.

Zokaeifar H, Balcazar JL, Saad CR, Kamarudin MS, Sijam K, Arshad A and Nejat N. (2012) Effects of Bacillus subtilis on the growth performance, digestive enzymes, immune gene expression and disease resistance of white shrimp (Litopenaeus vannamei). Fish Shellfish Immun. 33: 683-689. 